\title{
用語解説
}

\section{人工生命（Artificial Life, Alife）}

人工生命（Artificial Life, Alife）とは，「人工的に生命を構築する」という実践的手法により，構成論的に生命の本質を考察する という学問分野であり，その対象を単純に「人工生命」と呼ぶ。1 1986 年に理論物理学者クリストファー・ラングトンによって定義 されたが，その内容・分野は未だ特定・確立されているとは言い難く，研究者によって内容が異なる場合も多い. ラングトンによ る元々の概念に拠れば＜ life-as-we-know-it（我々が知っている生命）＞ではなく，〈life-as-it-could-be（あり得たかも知れない生命）>， すなわち＜自然の生命系に特有の振る舞いを示す人工的なシステム $>$ を人工生命 $>$ 定義して研究対象とし，これを創ることで 生命とは何かという疑問（生命系の論理形式）に答えることを究極の目標とした。彼の想定では生命とは物理的実体であるハード ウェアに依存したものではなく、ソフトウェアのような論理的な形式が本質であって，これを実装する媒体（メディア）は何であ っても良いと考えた，従って，計算機に実装されたプログラム，生物とは異なる化学反応系で構成されたウェットな物質系，機械 で構成されたドライ・ハード系のいずれも，生命的な振る舞いが発現すれば，それは人工生命であると考える，更にこの概念は 拡張されて，個体の生命体が集合して形成する社会系も人工生命としての振る舞いを発現しているという考えがあり，人工生命研 究 (ALIFE) は, 社会行動学の分野も含有する大きな学際的研究分野と捉えることが出来る. 1987 年にロスアラモス国立研究所に て開催された第 1 回目のワークショップ以来，国際会議が何度も開催され，現在は国際人工生命学会（The International Society for Artificial Life, ISAL）主催でAlife 国際会議が毎年開催されている。2018 年度の Alife2018 は東京で開催された。専門学術雑誌とし ては, ISAL の学会誌“Artificial Life（MIT Press）”がある. 人間中心の工学という意味で, ソフトコンピューティングの研究対象, 興味と重なる部分がある。

(関西学院大学 理工学部 人間システム工学科 工藤 卓)

\section{心の哲学 (Philosophy of Mind)}

一般的に，心や心の働きによって生じる現象，意識，心と<身体や外界と言った物理世界＞との関係性などについて考察する哲 学の分野であると理解されている。心の哲学という名称は近年よく用いられるが, これは哲学者デイビッド・ジョン・チャーマー ズらのようなこの分野における指導的な哲学者によるところが大きい. チャーマーズは所謂心身問題 (Mind-body problem)のうち, ＜物質としての脳から現象意識（主観的な意識体験，感覚質，クオリアとも呼ばれる）が如何にして生成されるのか＞という説明 困難な問題を「意識のハード・プロブレム（Hard problem of consciousness）」として，それ以外の比較的簡単な「意識のイージー . プロブレム（Easy problem of consciousness）」と分けて問題提起した，意識のイージー・プロブレムは，脳/神経回路網におお情 報処理の物理的過程を因果的に還元・記述することで解決される問題であるが，意識のハード・プロブレムはそれだけでは解決し にくい側面がある．現象意識が何故生ずるかについては，倫理的な付随性が明確であるような形で説明されなくてはならない，例 えば，オスの牝狐と言うものは論理的にあり得ないので，牝狐と言った瞬間にそれはオスではないということが自明となる。意識 のメカニズムが明らかになったとして，これをただ還元的に詳細に記述することと，このような論理的必然性によって意識を説明 することの間には大きなギャップがある，意識のハード・プロブレムと意識のイージー・プロブレムの間には，このような論理的 形式の差があるのであって，単に主観的な意識体験を外部から客観的に観測する方法が無いと言うような，方法論的な差異のみに 注目するのは間違いである.

主観的な意識体験と物質的な存在である脳・神経回路網との間の関係性については，大別して一元論，二元論，チャーマーズら も提唱する性質二元論が提唱されている。一元論は心と体は存在論的に不可分であると考える。これに対して二元論は心と体とは 別々に実体を持って存在していると考える，性質二元論とは，心的な世界そのものは物理的実体や原理に還元することはできない が，何らかの関連性を有しているとする考え方である。この場合，認識論的な解釈によって性質を定義し，物理現象に多重の意味 を関連づけるしかない，特にチャーマーズは，性質二元論で意識を説明するためには，既存の物理学を拡張する必要があると考え ている.

(関西学院大学 理工学部人間システム工学科 工藤卓) 